\title{
Characteristics and source identification of dissolved trace elements in the Jinshui River of the South Qinling Mts., China
}

\author{
Hongmei Bu ${ }^{1}$ - Weibo Wang ${ }^{2}$ - Xianfang Song ${ }^{1} \cdot$ Quanfa Zhang $^{2}$
}

Received: 2 June 2014 / Accepted: 4 May 2015 / Published online: 15 May 2015

(C) Springer-Verlag Berlin Heidelberg 2015

\begin{abstract}
Dissolved trace elements and physiochemical parameters were analyzed to investigate their physicochemical characteristics and identify their sources at 12 sampling sites of the Jinshui River in the South Qinling Mts., China from October 2006 to November 2008. The two-factor ANOVA indicated significant temporal variations of the dissolved $\mathrm{Cu}$, $\mathrm{Fe}, \mathrm{Sr}, \mathrm{Si}$, and $\mathrm{V}(p<0.001$ or $p<0.05)$. With the exception of $\mathrm{Sr}(p<0.001)$, no significant spatial variations were found. Distributions and concentrations of the dissolved trace elements displayed that dissolved $\mathrm{Cu}, \mathrm{Fe}, \mathrm{Sr}, \mathrm{Si}, \mathrm{V}$, and $\mathrm{Cr}$ were originated from chemical weathering and leaching from the soil and bedrock. Dissolved Cu, Fe, Sr, As, and Si were also from anthropogenic inputs (farming and domestic effluents). Correlation and regression analysis showed that the chemical and physical processes of dissolved $\mathrm{Cu}$ was influenced by water temperature and dissolved oxygen (DO) to some degree. Dissolved Fe and $\mathrm{Sr}$ were affected by colloid destabilization or sedimentary inputs. Concentrations of dissolved $\mathrm{Si}$ were slightly controlled by biological uptake. Principal component analysis confirmed that $\mathrm{Fe}, \mathrm{Sr}$, and $\mathrm{V}$ resulted from
\end{abstract}

Responsible editor: Céline Guéguen

Hongmei $\mathrm{Bu}$

buhm2004@163.com

Quanfa Zhang

qzhang@wbgcas.cn

1 Key Laboratory of Water Cycle and Related Land Surface Processes, Institute of Geographic Sciences and Natural Resources Research, Chinese Academy of Sciences, Datun Road, A 11, Beijing 100101, People's Republic of China

2 Key Laboratory of Aquatic Botany and Watershed Ecology, Wuhan Botanical Garden, Chinese Academy of Sciences, Wuhan 430074, People's Republic of China domestic effluents, agricultural runoff, and confluence, whereas $\mathrm{As}, \mathrm{Cu}$, and $\mathrm{Si}$ were from agricultural activities, and $\mathrm{Cr}$ and $\mathrm{Zn}$ through natural processes. The research results provide a reference for ecological restoration and protection of the river environment in the Qinling Mts., China.

Keywords Jinshui River · Dissolved trace elements · South Qinling Mts. · Spatiotemporal distribution · Statistical analysis · Source identification

\section{Introduction}

Trace elements in the natural environment are one of the primary pollutants due to their toxicity, persistence, and bioaccumulation problems (Morales et al. 1999; Pekey et al. 2004). More specifically, the presences of dissolved trace elements in many rivers present a threat to human health on a global level. The source of dissolved trace elements in rivers may be natural and occurs through events such as rock weathering, water erosion, and surface runoff (Martin et al. 1993; Pekey et al. 2004). Alternately, dissolved trace elements may originate from anthropogenic sources such as domestic sewage, agricultural runoff, industrial effluents, etc. (Caccia and Millero 2003; Mendiguchía et al. 2007).

There have been many studies that have investigated the geochemical processes of dissolved trace elements (Shiller and Boyle 1985, 1987; Neal et al. 1997; Zwolsman et al. 1997; Ramessur et al. 2001; Ravichandran 2003; Chaudry and Zwolsman 2008) as well as the sources of the pollution (Morales et al. 1999; Hatje et al. 2003; Pekey et al. 2004; Kuppusamy and Giridhar 2006; Mendiguchía et al. 2007; Zhou et al. 2007). These complex physicochemical processes are controlled by many factors, such as riverine input, precipitation, $\mathrm{pH}$, temperature, oxygen, nutrients, chemical sorption-desorption, and 
redox conditions (Zwolsman et al. 1997; Zhou et al. 2003; Caccia and Millero 2003; Hatje et al. 2003; Chaudry and Zwolsman 2008), which determine the addition and removal of dissolved trace elements in the riverine systems. It is essential that we fully understand these processes in order to remediate the contamination of dissolved trace elements in rivers (Martin et al. 1993; Elbaz-Poulichet et al. 2006).
The Qinling Mts. form the boundary between the Yellow River and the Yangtze River basins and are a natural barrier between North and South China. The Han River, a major tributary of the Yangtze River, is the water source of the middle line of the south-to-north water diversion project in the South Qinling Mts. (Zhang et al. 2009). In recent years, the water quality of the Han River has deteriorated by dissolved trace elements and

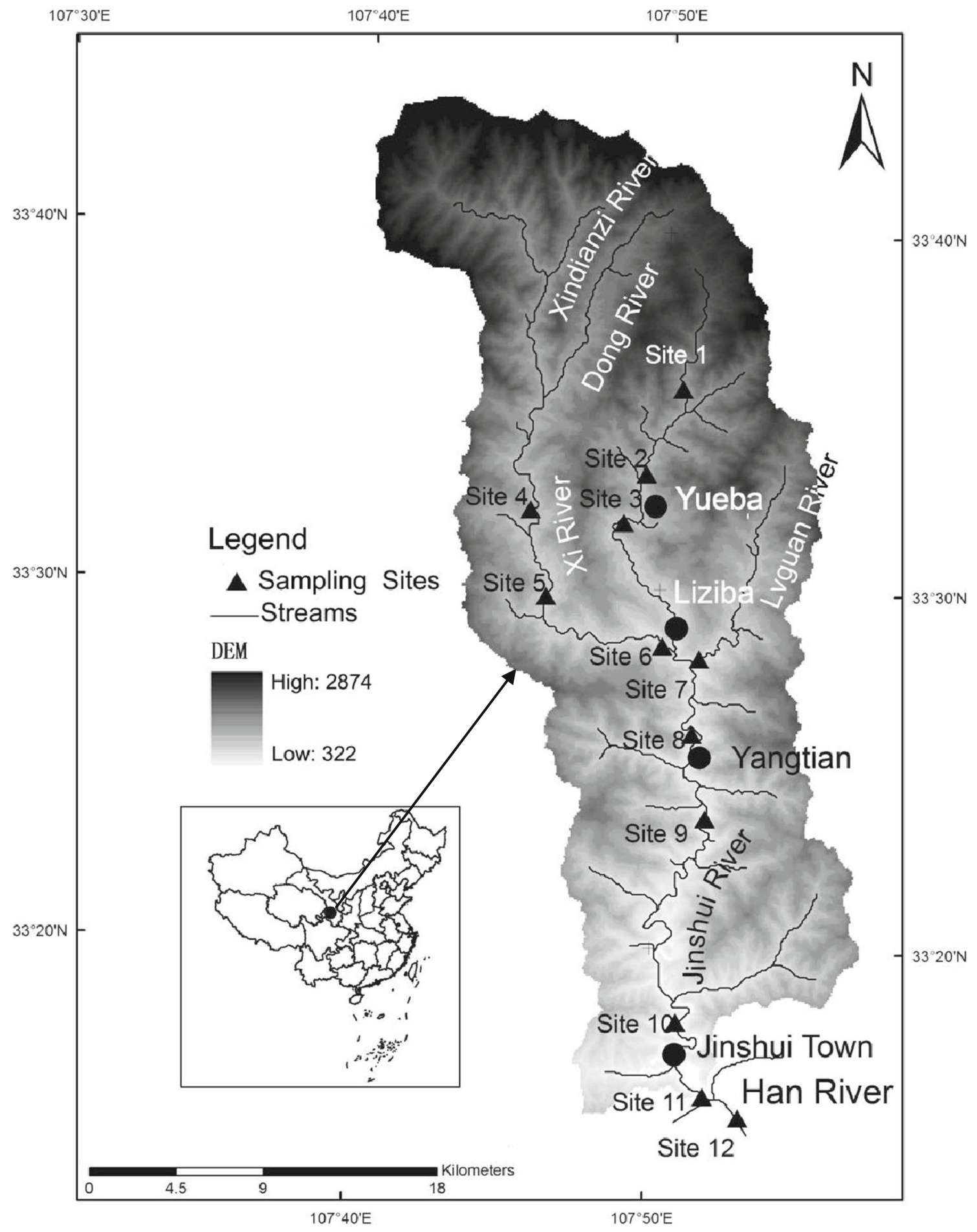

Fig. 1 The location and 12 sampling sites of the Jinshui River in the South Qingling Mts., China 
heavy metals due to increased economic development and the corresponding intensive human activities. This has been the subject of an environmental monitoring program for water and soil conservation in the Han River basin since 2004 (Zhang et al. 2009). In this study, we chose a major tributary of the Han River, the Jinshui River, to further investigate the environmental effects of trace elements in this region. Specifically, this study aims to 1) investigate the spatiotemporal distributions and concentrations of dissolved trace elements, 2) recognize the relationships among dissolved trace elements and physicochemical parameters, and 3) identify the sources of the dissolved trace elements.

\section{Materials and methods}

\section{Study area}

The Jinshui River $\left(33^{\circ} 16^{\prime}-33^{\circ} 45^{\prime} \mathrm{N}, 107^{\circ} 40^{\prime}-108^{\circ} 10^{\prime} \mathrm{E}\right)$ of the upper Han River is located in the South Qinling Mts. in Shaanxi Province of China. It drains an area of $730 \mathrm{~km}^{2}$ with a total length of $87 \mathrm{~km}$ and includes four major tributaries, i.e., Xi River, Xindianzi River, Dong River, and Lvguan River (Fig. 1). The river's flow velocity changes over different seasons. The mean flow velocity in the river is about $0.5 \mathrm{~m}^{3} / \mathrm{s}$ in the mean-flow period, $0.4 \mathrm{~m}^{3} / \mathrm{s}$ in the low-flow period, and $0.8 \mathrm{~m}^{3} / \mathrm{s}$ in the high-flow period.

The river basin is in a humid monsoon climate zone. The annual average temperature in the catchment is approximately $11.5^{\circ} \mathrm{C}$, while the highest is $21.9^{\circ} \mathrm{C}$ in summer and the lowest $-0.3{ }^{\circ} \mathrm{C}$ in winter. The rainfall varies between 924 and $1240 \mathrm{~mm}$ per year, and most of the rainfall occurs from June to August. The soil types include paddy soil, yellow cinnamon soil, yellow brown soil, brown soil, and dark brown forest soil along elevational gradients.

The Jinshui River basin is a typical mountainous catchment in the South Qinling Mts. with intensive forest cover (96.4\% of the drainage area) (Shen et al. 2006). Upstream of the river lies in the Foping National Nature Reserve, which with a forest cover of $97.47 \%$, has been established primarily for giant panda conservation. Forest and shrubland are the major land use types and arable land is scattered in the midstream of the river. Of the total populations of 19.21 thousand, $51.39 \%$ of the total populations (19.21 thousand) and $94.06 \%$ of the agricultural lands in the catchment are distributed in the lower reaches of the river, especially in Jinshui Town. However, no industrial activities exist in the basin.

\section{Sampling}

Water samplings have been conducted nine times between October 2006 and November 2008. Three of these samplings were carried out during the high-flow period (October 2006, August 2007, and August 2008), three in the low-flow period
(December 2006, March 2007, and March 2008), and the other three in the mean-flow period (May and November 2007 and November 2008). There were 12 sampling sites along the river (Fig. 1), of which, sites 1-5, sites 6-9, and sites 10-12 are located in the upper, middle, and lower river, respectively. Site 10 is located close to Jinshui Town where there is a population of 9,837. Meanwhile, site 12 is the confluence of the two rivers between the Jinshui River and the Han River. Approximately, 108 water samples were obtained during the sampling periods.

Physicochemical parameters including water temperature (Temp), dissolved oxygen (DO), $\mathrm{pH}$, total dissolved solids (TDS), and nitrate nitrogen $\left(\mathrm{NO}_{3}-\mathrm{N}\right)$ were measured in situ using multiparameter water quality monitoring instrument (YSI Incorporated, Yellow Springs, OH, USA). Calibration of sensors was performed before every survey. For analysis of dissolved trace elements and dissolved phosphate (DP), water samples were filtrated through cellulose nitrate membrane filters with pore size of $0.45 \mu \mathrm{m}$ (Millipore, USA) and then stored for further analysis in acid-cleaned polyethylene bottles that were acidified to $\mathrm{pH}<2$ with high-purity nitric acid.

\section{Analytical methods}

Dissolved trace elements and DP were quantified by inductively coupled plasma atomic emission spectrometer (ICPAES) (IRIS Intrepid II XSP DUO, USA). Method accuracy and quality control were verified by triplicate analysis of standard reference material (SRM, SPEX CertiPrep, Inc., USA). A good agreement was observed between the data analyzed and those certified by the SRM (Table 1). Concentrations of $\mathrm{Cd}, \mathrm{Co}, \mathrm{Ni}, \mathrm{Mo}$, and $\mathrm{Mn}$ were below the detection limits and not shown here. Thus, dissolved trace

Table 1 Quality control data of SRM analysis and detection limits for the dissolved trace elements and DP using ICP-AES

\begin{tabular}{lllll}
\hline $\begin{array}{l}\text { Analyzed } \\
\text { parameter }\end{array}$ & $\begin{array}{l}\text { Detection } \\
\text { limit }(\mu \mathrm{g} / \mathrm{l})\end{array}$ & $\begin{array}{l}\text { SRM } \\
\text { certified }(\mu \mathrm{g} / \mathrm{l})\end{array}$ & $\begin{array}{l}\text { SRM } \\
\text { analyzed }(\mu \mathrm{g} / \mathrm{l})\end{array}$ & \% recovery \\
\hline $\mathrm{DP}$ & 4 & 1.0 & 0.998 & 99.80 \\
$\mathrm{As}$ & 2 & 1.0 & 1.030 & 103.00 \\
$\mathrm{Cu}$ & 3 & 0.5 & 0.513 & 102.60 \\
$\mathrm{Fe}$ & 10 & 4.0 & 4.102 & 102.55 \\
$\mathrm{Cr}$ & 5 & 1.0 & 1.046 & 104.60 \\
$\mathrm{Sr}$ & 5 & 2.0 & 2.088 & 104.40 \\
$\mathrm{Si}$ & 20 & 5.0 & 5.272 & 105.44 \\
$\mathrm{~V}$ & 5 & 1.0 & 1.023 & 102.30 \\
$\mathrm{Zn}$ & 2 & 2.0 & 2.106 & 105.30 \\
$\mathrm{Cd}$ & 5 & 0.8 & 0.801 & 100.13 \\
$\mathrm{Co}$ & 5 & 1.0 & 1.002 & 100.20 \\
$\mathrm{Ni}$ & 3 & 2.0 & 2.026 & 101.30 \\
$\mathrm{Mo}$ & 10 & 2.0 & 2.002 & 100.10 \\
$\mathrm{Mn}$ & 5 & 2.0 & 2.054 & 102.70 \\
\hline
\end{tabular}


elements of $\mathrm{As}, \mathrm{Cu}, \mathrm{Fe}, \mathrm{Cr}, \mathrm{Sr}, \mathrm{Si}, \mathrm{V}$, and $\mathrm{Zn}$ were selected for further analyses.

\section{Statistical analysis}

The two-factor ANOVA was performed to examine the influence of different sampling sites and flow periods on dissolved trace elements, physicochemical parameters, and their interaction effects (Hatje et al. 2003; Mendiguchía et al. 2007). Normality and homogeneity of variances were evaluated using the one-sample Kolmogorov-Smirnov and Levene's tests, respectively. Logarithmic transformations were required for TDS, $\mathrm{NO}_{3}-\mathrm{N}, \mathrm{DP}$, As, Fe, Cr, and Sr. For abnormally distributed or unequal variance variables $(p<0.05)$, the non-parametric Dunnett's test was used (Bu et al., 2010, 2014). Multiple comparisons were conducted using Student-Newman-Keuls (SNK). Correlation and regression analyses were used to explore the relationships among the variables (Zhou et al. 2003). In order to identify the sources of pollutants, principal component analysis (PCA) was operated by using Varimax Kaiser Normalization, only eigenvalues greater than or equal to 1 were considered as possible sources of variance (Kowalkowski et al. 2006). All statistical analyses were all performed by using SPSS 13.0.

\section{Results and discussions}

\section{Spatiotemporal distributions and concentrations of the physicochemical parameters}

Spatiotemporal distributions of physicochemical parameters are plotted in Fig. 2, and show no significant spatial
Fig. 2 Spatiotemporal series of physicochemical parameter concentrations associated with dissolved trace elements in the Jinshui River, China
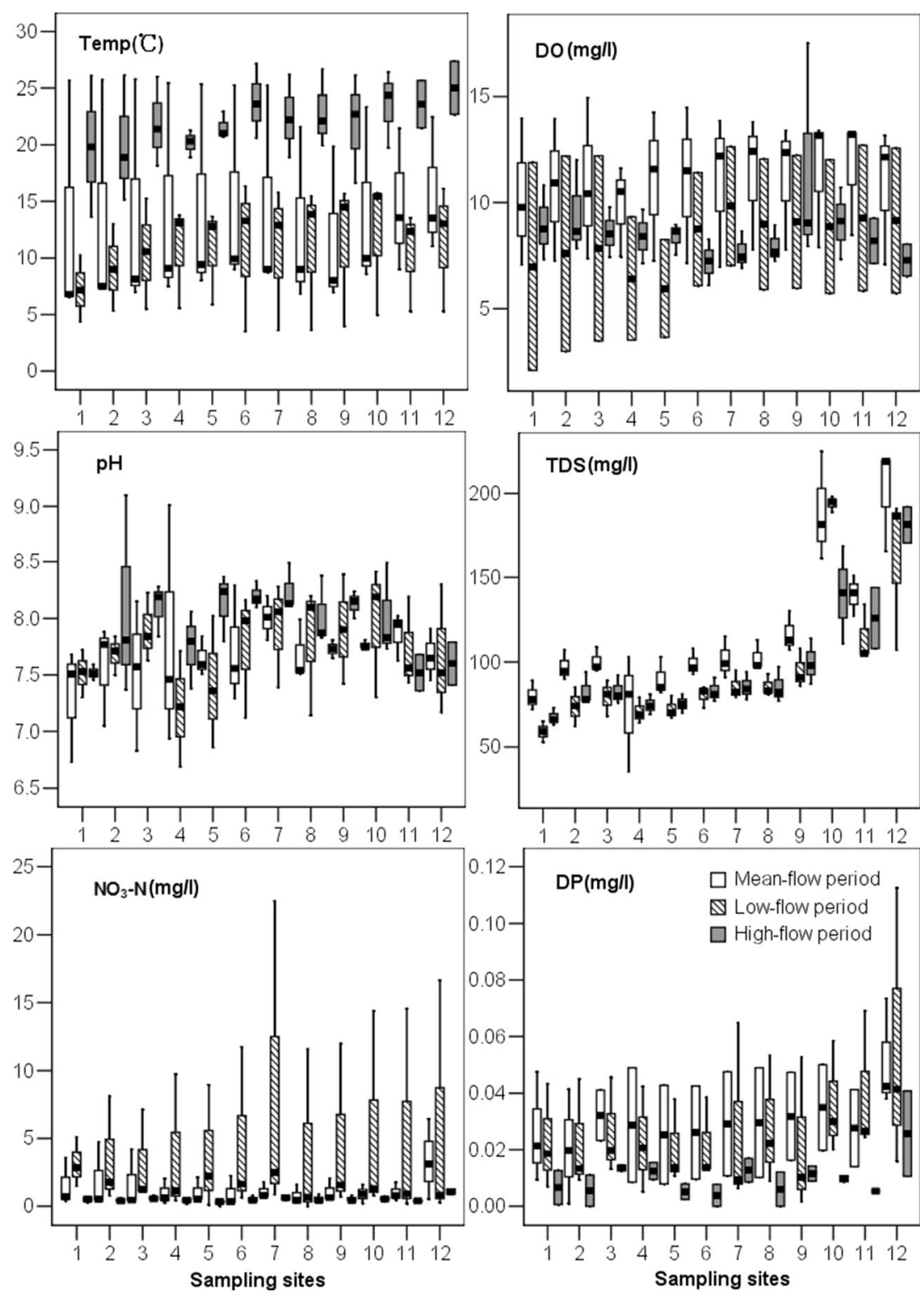
variabilities except TDS ( $p<0.001$; Table 2$)$. Water temperature, TDS, and $\mathrm{NO}_{3}-\mathrm{N}$ present significant seasonal variations $(p<0.001$, Table 2$)$ during the sampling periods. Water temperature ranges from 6.55 to $25.78^{\circ} \mathrm{C}$ in the mean-flow period, from 3.50 to $16.33{ }^{\circ} \mathrm{C}$ in the low-flow period, and from 13.62 to $27.36{ }^{\circ} \mathrm{C}$ in the high-flow period. The TDS concentrations display large ranges of $35-225 \mathrm{mg} / \mathrm{l}$ during the meanflow period in the Jinshui River. The $\mathrm{NO}_{3}-\mathrm{N}$ has significant high concentrations in the low-flow period with values ranging from 0.034 to $22.490 \mathrm{mg} / \mathrm{l}$. Dissolved oxygen, $\mathrm{pH}$, and DP also have significant seasonal variations at $p<0.05$ level (Table 2) during the sampling periods. The mean concentration of DO in the Jinshui River is $9.40 \pm 3.05 \mathrm{mg} / \mathrm{l}$ (mean \pm S.D.), showing a high value. Values for $\mathrm{pH}$ range from slightly acid (6.7) during mean-flow and low-flow periods to alkaline (9.1) during high-flow period. The mean DP concentrations show relatively high values $(0.031 \pm 0.019 \mathrm{mg} / \mathrm{l})$ during meanflow period.

However, none of the physicochemical parameters have interaction effects between different sampling sites and flow periods. Large changes in $\mathrm{pH}$ values (6.7-9.1) occur among the different sampling sites during the sampling periods. Mean concentrations of TDS at sites $10(174.33 \pm 33.83 \mathrm{mg} / \mathrm{l})$ and 12 $(181.25 \pm 35.98 \mathrm{mg} / \mathrm{l})$ are much higher than those in other sampling sites. The peak value of $\mathrm{NO}_{3}-\mathrm{N}(22.490 \mathrm{mg} / \mathrm{l})$ appears at site 7 during the low-flow period, while the maximum mean concentration of $\mathrm{NO}_{3}-\mathrm{N}(3.753 \pm 5.593 \mathrm{mg} / \mathrm{l})$ occurs at site 12. Dissolved phosphate displays the same trend as $\mathrm{NO}_{3}$ -
$\mathrm{N}$ at different sampling sites; however, its concentrations is highest at site $12(0.113 \mathrm{mg} / \mathrm{l})$ during mean-flow period.

\section{Spatiotemporal distributions and concentrations of the dissolved trace elements}

The spatiotemporal variations of dissolved trace elements are shown in Fig. 3. Dissolved trace elements demonstrate no significant spatial patterns except in the case of $\mathrm{Sr}$ $(p<0.001)$. However, dissolved $\mathrm{Cu}, \mathrm{Fe}, \mathrm{Sr}, \mathrm{Si}$, and $\mathrm{V}$ show significant temporal trends $(p<0.001$ or $p<0.05$; Table 2$)$, showing common origin from chemical weathering and leaching from the soil and bedrock. Dissolved $\mathrm{Cu}$ and $\mathrm{Fe}$ have much higher values in the low-flow period than in the meanflow and high-flow periods, with mean values of 15.6 and $117 \mu \mathrm{g} / \mathrm{l}$, respectively. Additionally, dissolved $\mathrm{Sr}$ has a significant interaction effect $(p<0.05)$ between different sampling sites and sampling periods, showing its multiple sources in the river. High mean concentrations of dissolved Si (7.05 \pm $2.77 \mathrm{mg} / \mathrm{l})$ and $\mathrm{V}(116 \pm 118 \mu \mathrm{g} / \mathrm{l})$ are all found in high-flow period, indicating their some sources from soil erosion during rainy season (Wang et al. 2009).

Dissolved trace elements still display some spatial characteristics although they have no significant spatial variations with the exception of Sr. Peak values of dissolved As and $\mathrm{Si}$ $(22 \mu \mathrm{g} / \mathrm{l}$ and $11.24 \mathrm{mg} / \mathrm{l})$ occur at sites 6 and 10 , respectively. The results are due to anthropogenic inputs, such as farming crops and releasing domestic effluents (Mendiguchía et al.

Table 2 Summary of two-factor ANOVA on the spatiotemporal variations of physicochemical parameters and dissolved trace elements in the Jinshui River, China

\begin{tabular}{|c|c|c|c|c|c|c|c|c|c|c|c|c|c|c|c|c|}
\hline \multirow[t]{2}{*}{ Source of variation } & \multirow[t]{2}{*}{$d f$} & \multicolumn{3}{|l|}{ Temp } & \multicolumn{3}{|l|}{ DO } & \multicolumn{3}{|l|}{$\mathrm{pH}$} & \multicolumn{3}{|l|}{ TDS } & \multicolumn{3}{|l|}{$\mathrm{NO}_{3}-\mathrm{N}$} \\
\hline & & MS & $F$ & $p$ & MS & $F$ & $p$ & MS & $F$ & $p$ & MS & $F$ & $p$ & MS & $F$ & $p$ \\
\hline Periods (Pr) & 2 & 1241.070 & 29.461 & $* *$ & 71.179 & 6.459 & * & 0.701 & 3.632 & * & 0.004 & 14.140 & $* *$ & 168.624 & 10.119 & $* *$ \\
\hline Sites $(\mathrm{St})$ & 11 & 10.227 & 0.243 & ns & 3.104 & 0.282 & ns & 0.249 & 1.288 & ns & 0.012 & 44.961 & $* *$ & 3.246 & 0.195 & ns \\
\hline $\operatorname{Pr} \times \mathrm{St}$ & 22 & 2.775 & 0.066 & ns & 2.373 & 0.215 & ns & 0.101 & 0.521 & ns & 0.000 & 1.093 & $\mathrm{~ns}$ & 2.645 & 0.159 & ns \\
\hline Residual & 70 & 42.125 & & & 11.020 & & & 0.193 & & & 0.000 & & & 16.663 & & \\
\hline \multirow[t]{2}{*}{ Source of variation } & $d f$ & $\mathrm{DP}$ & & & As & & & $\mathrm{Cu}$ & & & $\mathrm{Fe}$ & & & $\mathrm{Cr}$ & & \\
\hline & & MS & $F$ & $p$ & MS & $F$ & $p$ & MS & $F$ & $p$ & MS & $F$ & $p$ & MS & $F$ & $p$ \\
\hline Periods (Pr) & 2 & 0.003 & 6.764 & $*$ & 97.737 & 3.225 & ns & 638.301 & 13.635 & $* *$ & $69,379.480$ & 5.847 & $*$ & 608.954 & 2.780 & $\mathrm{~ns}$ \\
\hline Sites $(\mathrm{St})$ & 11 & 0.000 & 0.917 & ns & 30.211 & 0.997 & ns & 13.903 & 0.297 & ns & $11,261.188$ & 0.949 & ns & 51.819 & 0.237 & ns \\
\hline $\operatorname{Pr} \times \mathrm{St}$ & 22 & 0.000 & 0.093 & ns & 16.922 & 0.558 & ns & 18.262 & 0.390 & ns & $13,174.353$ & 1.110 & ns & 49.682 & 0.227 & $\mathrm{~ns}$ \\
\hline Residual & 70 & 0.000 & & & 30.307 & & & 46.813 & & & $11,865.606$ & & & 219.034 & & \\
\hline \multirow[t]{2}{*}{ Source of variation } & $d f$ & $\mathrm{Sr}$ & & & $\mathrm{Si}$ & & & $\mathrm{V}$ & & & $\mathrm{Zn}$ & & & & & \\
\hline & & MS & $F$ & $p$ & MS & $F$ & $p$ & MS & $F$ & $p$ & MS & $F$ & $p$ & & & \\
\hline Periods (Pr) & 2 & 896.946 & 5.047 & $*$ & 98.744 & 14.327 & $* *$ & $90,495.007$ & 11.725 & $* *$ & 326.586 & 2.144 & ns & & & \\
\hline Sites $(\mathrm{St})$ & 11 & $18,445.117$ & 103.794 & $* *$ & 3.181 & 0.528 & ns & 402.194 & 0.052 & $\mathrm{~ns}$ & 88.038 & 0.578 & $\mathrm{~ns}$ & & & \\
\hline $\operatorname{Pr} \times \mathrm{St}$ & 22 & 456.632 & 2.570 & $*$ & 0.775 & 0.145 & ns & 231.429 & 0.030 & ns & 65.299 & 0.429 & $\mathrm{~ns}$ & & & \\
\hline Residual & 70 & 177.709 & & & 6.658 & & & 7717.871 & & & 152.329 & & & & & \\
\hline
\end{tabular}

$d f$ degrees of freedom, $M S$ mean square, $n s$ not significant

*Represents significance at $p \leq 0.05$

$* *$ Represents significance at $p \leq 0.001$ 
Fig. 3 Spatiotemporal series of dissolved trace element concentrations in the Jinshui River, China
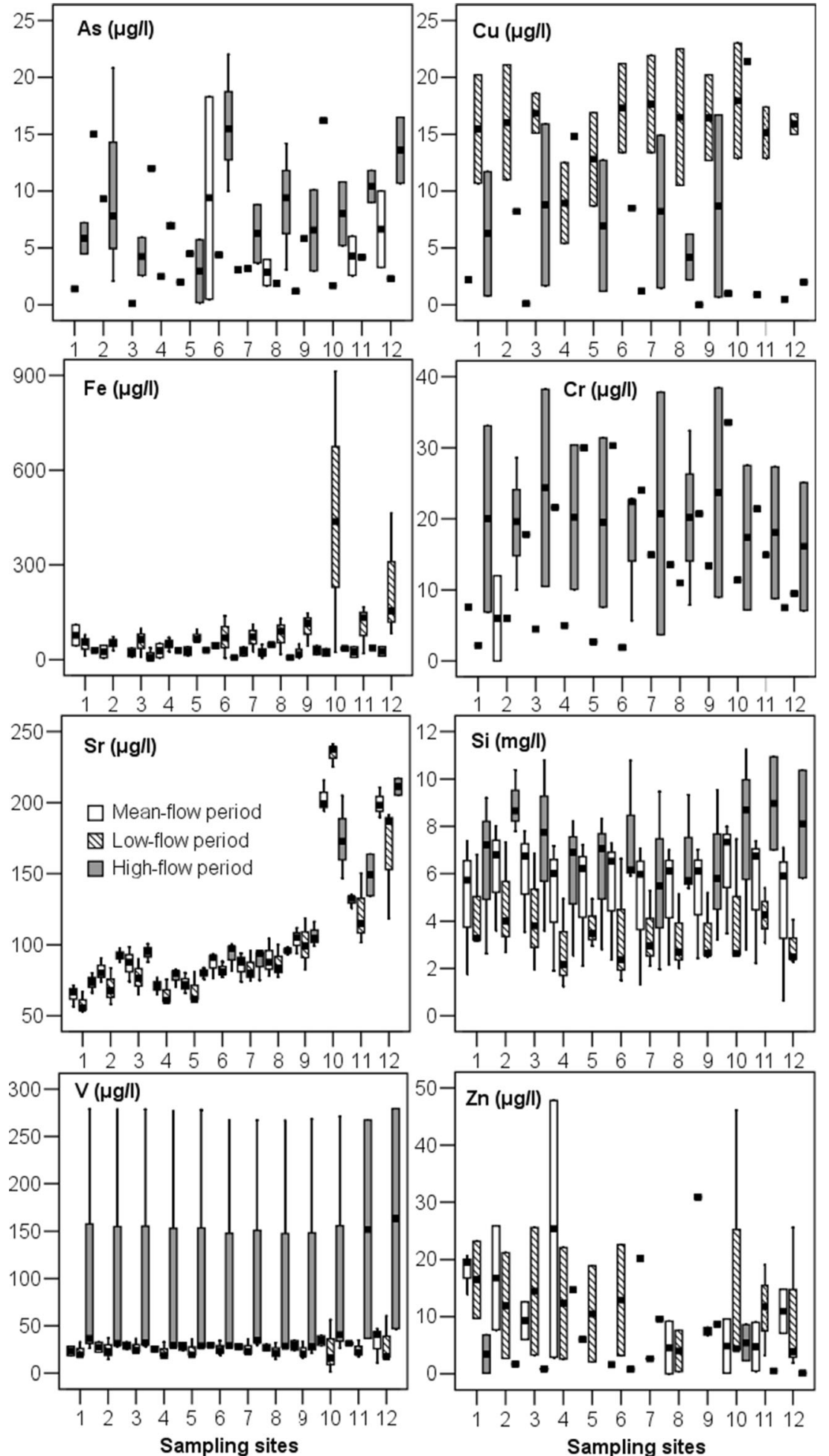

2007). The maximum values of dissolved $\mathrm{Cu}(23 \mu \mathrm{g} / \mathrm{l}), \mathrm{Fe}$ $(913 \mu \mathrm{g} / \mathrm{l})$, and $\mathrm{Sr}(241 \mu \mathrm{g} / \mathrm{l})$ are observed at site 10 closing to Jinshui Town (Fig. 1) in the low-flow period, suggesting their common origin from anthropogenic sources (Martin et al. 1993; Kumaresan and Riyazuddin 2008). Dissolved $\mathrm{Cr}$, however, has the maximum $(38 \mu \mathrm{g} / \mathrm{l})$ at site 9 in the high-flow period, affected by soil erosion (Crosa et al. 2006). During the three sampling periods, the maximum levels of dissolved $\mathrm{V}$ occur at site 12 , revealing the hydrological and chemical differences may be due to the confluence of the Jinshui River and Han River (Ravichandran 2003). 
The concentrations of dissolved $\mathrm{Cu}, \mathrm{Fe}, \mathrm{Cr}$, and $\mathrm{Zn}$ (Fig. 3) are all below WHO recommendations (2004) for drinking water $(2000,2000,50$, and $3000 \mu \mathrm{g} / 1$ for $\mathrm{Cu}, \mathrm{Fe}, \mathrm{Cr}$, and $\mathrm{Zn}$, respectively). Similarly, these concentrations with the exception of $\mathrm{Fe}$, generally fall within the Chinese standards (2006) for drinking water $(1000,300,50$, and $1000 \mu \mathrm{g} / \mathrm{l}$ for $\mathrm{Cu}, \mathrm{Fe}, \mathrm{Cr}$, and $\mathrm{Zn}$, respectively). The concentrations of dissolved As in most sampling sites, have high values and are higher than $10 \mu \mathrm{g} / \mathrm{l}$ in the high-flow period, which exceed the WHO recommendations and Chinese standards for drinking water. Thus, the dissolved As may be introduced into the river by soil erosion in the rainy season (Crosa et al. 2006). The mean concentrations of dissolved $\mathrm{Sr}$ from site 9 to site 12 exceed levels observed in sites 1-8 by one order of magnitude, indicating that the sources of $\mathrm{Sr}$ are not only from atmospheric and weathering endmembers but also from anthropogenic activities.

\section{Relationships among dissolved trace elements, physicochemical parameters, and inorganic nutrients}

Correlations between dissolved trace elements and physicochemical variables are presented in Table 3. Dissolved $\mathrm{Cu}$ and $\mathrm{V}$ are significantly correlated with water temperature $(p<0.01)$. This may suggest a temperature effect on a series of chemical and physical processes including adsorption (Fedoseyeva 1995; Shiller 1997), formation of complexes, and ion exchange (Morales et al. 1999; Kuppusamy and Giridhar 2006) in the rivers. Dissolved $\mathrm{Cu}$ is also negatively correlated to DO $(r=-0.454, p<0.01)$; thus, its concentrations may be determined by oxidation-reduction processes due to its oxidability (Hatje et al. 2003). Since $\mathrm{pH}$ values in the river vary over a relatively large range, the dissolved trace elements do not show any significant $\mathrm{pH}$-related change (Shiller and Boyle 1987; Shiller 1997). Dissolved $\mathrm{Fe}$ and $\mathrm{Sr}$ are positively correlated to TDS concentrations $(p<0.01)$, respectively. The correlations indicate that the dissolved trace elements in the Jinshui River are affected by colloid destabilization (Wang et al. 2009) or sedimentary inputs (Shiller and Boyle 1985). Dissolved Sr concentrations are strongly bound by TDS contents and linearly increase with them $\left(r^{2}=0.854, p<0.001\right.$; Fig. 4a), suggesting a relationship of regulation effect.

The relationships among dissolved trace elements and nutrients are shown in Table 3. Dissolved $\mathrm{Cu}$ and $\mathrm{Fe}$ are positively associated with concentrations of $\mathrm{NO}_{3}-\mathrm{N}(p<0.01)$ since they display similar temporal patterns with $\mathrm{NO}_{3}-\mathrm{N}$ (Figs. 2 and 3), indicating part of the same sources from domestic effluents in low-flow period. Dissolved $\mathrm{Cu}$ also displays a quadratic trend with $\mathrm{NO}_{3}-\mathrm{N}\left(r^{2}=0.392, p<0.001\right.$; Fig. $4 b)$. This could be explained by the influences of redox chemistry since nitrate is a fair measure of the redox condition in the river (anoxic) water column (Zwolsman et al. 1997). The inverse relationship between $\mathrm{Si}$ and $\mathrm{NO}_{3}-\mathrm{N}(p<0.01)$ indicates that $\mathrm{Si}$ is also possibly affected by biological uptake (Wang et al. 2009), such as floating algae (Ramessur et al. 2001), particularly by diatoms, since 194 taxa of benthic diatoms from 31 genera were identified in the upper Han River (Tan et al. 2013).

Dissolved As and $\mathrm{Cu}$ have strong negative affiliations with the DP values $(p<0.01)$. Additionally, they follow a quadratic decrease $\left(r^{2}=0.570, p<0.001\right.$; Fig. $\left.4 \mathrm{c}\right)$ and a cubic trend $\left(r^{2}=\right.$ $0.613, p<0.001$; Fig. 4d) with DP, respectively, displaying removal trends for uptake of phytoplankton as substitutes for DP in the growing periods (Elbaz-Poulichet et al. 2006),

Table 3 Correlations among the dissolved trace elements and physicochemical parameters

\begin{tabular}{|c|c|c|c|c|c|c|c|c|c|c|c|c|c|c|}
\hline & Temp & DO & $\mathrm{pH}$ & TDS & $\mathrm{NO}_{3}-\mathrm{N}$ & DP & As & $\mathrm{Cu}$ & $\mathrm{Fe}$ & $\mathrm{Cr}$ & $\mathrm{Sr}$ & $\mathrm{Si}$ & $\mathrm{V}$ & $\mathrm{Zn}$ \\
\hline Temp & 1 & & & & & & & & & & & & & \\
\hline DO & $-0.256^{*}$ & 1 & & & & & & & & & & & & \\
\hline $\mathrm{pH}$ & $0.361 * *$ & 0.059 & 1 & & & & & & & & & & & \\
\hline TDS & -0.025 & 0.123 & -0.082 & 1 & & & & & & & & & & \\
\hline $\mathrm{NO}_{3}-\mathrm{N}$ & $-0.560^{* *}$ & $-0.403 * *$ & $-0.327 * *$ & 0.178 & 1 & & & & & & & & & \\
\hline DP & $-0.273^{* *}$ & $0.456^{* *}$ & -0.142 & $0.348^{* *}$ & -0.079 & 1 & & & & & & & & \\
\hline As & 0.221 & -0.298 & 0.112 & 0.166 & 0.171 & $-0.673^{* *}$ & 1 & & & & & & & \\
\hline $\mathrm{Cu}$ & $-0.448 * *$ & $-0.454 * *$ & -0.011 & -0.021 & $0.596^{* *}$ & $-0.575^{* *}$ & $0.893^{* *}$ & 1 & & & & & & \\
\hline $\mathrm{Fe}$ & -0.214 & -0.023 & -0.066 & $0.412^{* *}$ & $0.314^{* *}$ & -0.083 & -0.211 & 0.272 & 1 & & & & & \\
\hline $\mathrm{Cr}$ & 0.012 & 0.151 & 0.178 & -0.123 & $-0.304^{*}$ & 0.164 & -0.165 & -0.169 & -0.139 & 1 & & & & \\
\hline $\mathrm{Sr}$ & 0.136 & -0.024 & 0.041 & $0.924 * *$ & 0.140 & $0.261^{*}$ & 0.164 & -0.004 & $0.469 * *$ & 0.049 & 1 & & & \\
\hline $\mathrm{Si}$ & 0.170 & $0.215^{*}$ & 0.027 & 0.059 & $-0.294^{* *}$ & $0.347 * *$ & -0.020 & $-0.792 * *$ & $-0.309 * *$ & $0.641 * *$ & 0.083 & 1 & & \\
\hline $\mathrm{V}$ & $0.341 * *$ & -0.061 & 0.085 & -0.084 & -0.191 & 0.208 & -0.103 & $-0.550^{* *}$ & -0.195 & $0.705^{* *}$ & 0.064 & $0.659 * *$ & 1 & \\
\hline $\mathrm{Zn}$ & -0.248 & -0.115 & -0.050 & -0.064 & 0.162 & $0.312^{*}$ & -0.311 & $0.384^{*}$ & -0.019 & $-0.387 *$ & -0.070 & -0.017 & -0.221 & 1 \\
\hline
\end{tabular}

*Correlation is significant at the 0.05 level (two-tailed)

**Correlation is significant at the 0.01 level (two-tailed) 
Fig. 4 a-d Regression analyses of TDS with dissolved $\mathrm{Sr}$ and nutrient elements with dissolved $\mathrm{Cu}$ and $\mathrm{As}$
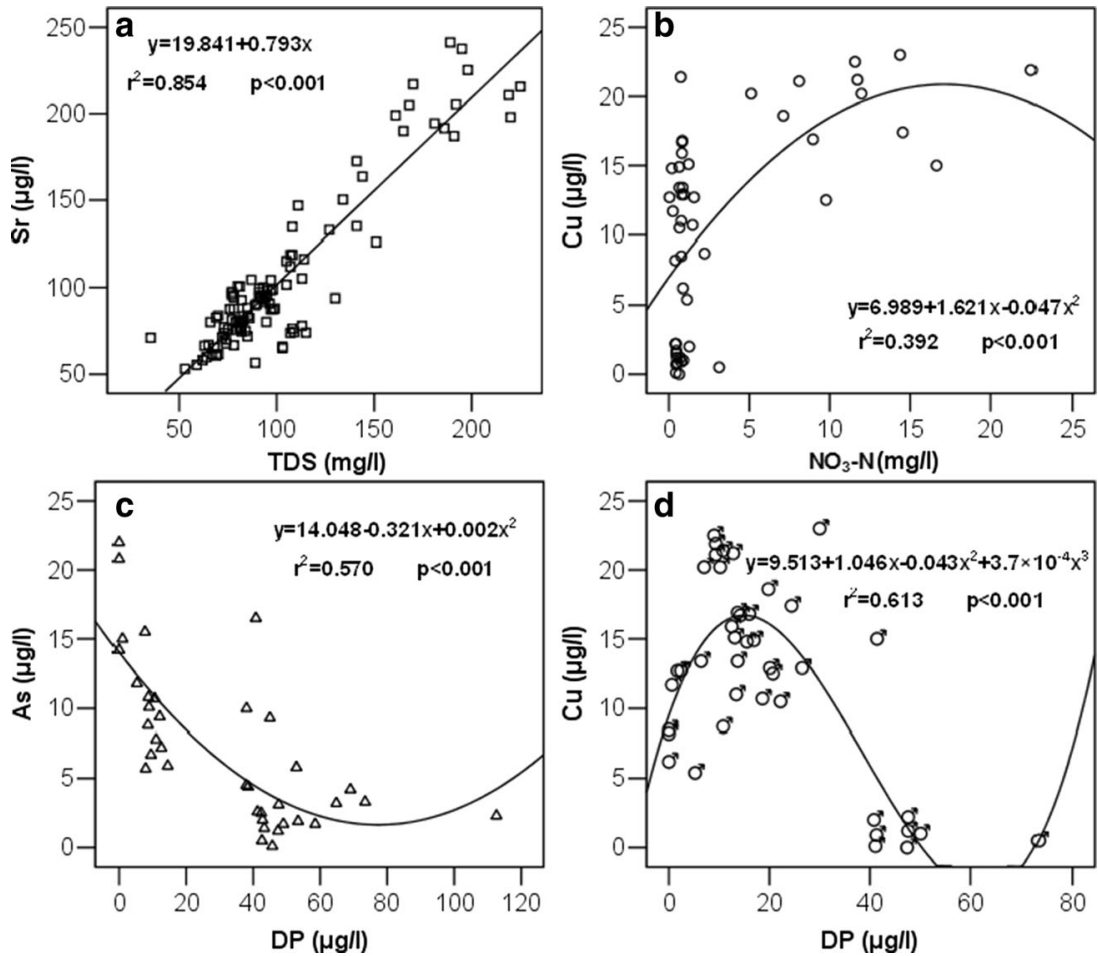

especially in May of the mean-flow period. Meanwhile, Dissolved $\mathrm{Si}, \mathrm{Sr}$, and $\mathrm{Zn}$ are positively related to $\mathrm{DP}(p<0.01$ or $p<0.05$ ), indicating their similarities in chemical properties and origin (Caccia and Millero 2003).

Dissolved $\mathrm{As}$ and $\mathrm{Cu}$ are significantly correlated $(r=0.893$, $p<0.01$ ) with each other (Table 3 ), suggesting a common origin from anthropogenic sources (Kumaresan and Riyazuddin 2008), such as agricultural activities. Most likely, dissolved $\mathrm{Cu}$ and $\mathrm{Fe}$ concentrations are determined by the local redox rate. However, the silicate input can change this condition, leading to the precipitation of $\mathrm{Cu}-\mathrm{Fe}$ oxides (Elbaz-Poulichet et al. 2006). Therefore, significant negative correlations are observed between the two elements and dissolved $\mathrm{Si}$ $(p<0.01)$. Dissolved V is correlated to the studied trace elements of $\mathrm{Cu}, \mathrm{Cr}$, and $\mathrm{Si}(p<0.01$; Table 3$)$, which implies that these related elements are likely driven by similar hydrologic and geochemical processes (Neal et al. 1997; Zhou et al. 2003). In addition, dissolved $\mathrm{Zn}$ demonstrates significant correlations with positive $\mathrm{Cu}$ and negative $\mathrm{Cr}(p<0.05$; Table 3), since it is prone to be adsorbed and oxidized in rivers (Shiller and Boyle 1985).

\section{Source identification of the dissolved trace elements}

PCA is carried out for dissolved trace elements in river water to explore their sources (Zhou et al. 2007). The Kaiser-Meyer-Olkin (KMO) and Bartlett's test of sphericity were used to detect the sampling adequacy and examine the validity of PCA. The results of KMO and Bartlett's test were 0.198 and $60.229(d f=28, p<0.01)$, respectively, implying that PCA would be effective in reducing dimensionality. Four principal components (PCs) were extracted (eigenvalues $>1$ ), explaining $88.39 \%$ of the total variance. Afterwards, four varifactors (VFs) were obtained by the four rotated PCs.

In order to identify the source apportionment, the scores of sampling sites and loadings of variables associated with VF1 and VF2 were plotted on a plane graph (Fig. 5). The sampling sites could be divided into three groups which are consistent with the four VFs. The first group is correlated with sampling

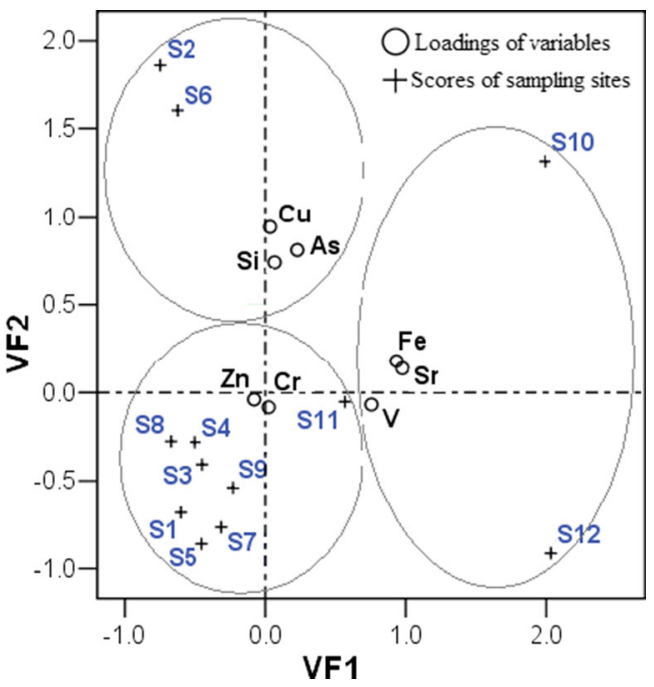

Fig. 5 Plane graph on scores of sampling sites and loadings of variables defined by the first two rotated factors (S1 12 represents sampling sites 1 12) 
sites 10 and 12, located in the lower reaches of the river. The relevant variables in the first group are $\mathrm{Fe}, \mathrm{Sr}$, and $\mathrm{V}$, which may originate from domestic effluents, agricultural runoff, and confluence with the Han River. The second group includes sites 2 and 6 , corresponding to $\mathrm{As}, \mathrm{Cu}$, and $\mathrm{Si}$, confirming their anthropogenic sources due to agricultural activities. Sites 1, 3-5, 7-9, and 11 comprise the third group, where the observed levels of dissolved $\mathrm{Cr}$ and $\mathrm{Zn}$ are from natural sources, such as erosion and weathering of rock (Martin et al. 1993).

\section{Conclusions}

Dissolved $\mathrm{Cu}, \mathrm{Fe}, \mathrm{Sr}, \mathrm{Si}$, and $\mathrm{V}$ display significant temporal trends rather than spatial patterns in the Jinshui River, with an exception of dissolved Sr. Additionally, the relationships between the dissolved trace elements and associated parameters demonstrate their chemical and physical processes. Furthermore, four groups of source apportionment are identified, reflecting origins from anthropogenic (domestic effluents, agricultural runoff, and confluence with the Han River) and natural (erosion and weathering) sources. The analytical results for the Jinshui River provide an important basis for the ecological restoration and protection of the river system in the South Qinling Mts. Moreover, this study provides useful information on the hydrology and water quality of river environment for the middle line of the south-to-north water diversion project.

Acknowledgments This research is supported by the National Natural Science Foundation of China (Grant No. 41103069) and the Open Funding Project of the Key Laboratory of Aquatic Botany and Watershed Ecology, Chinese Academy of Sciences. The authors express sincere gratitude to Cen Wang and Mingyong Zhu for their assistance during the fieldwork.

\section{References}

Bu H, Tan X, Li S, Zhang Q (2010) Temporal and spatial variations of water quality in the Jinshui River of the South Qinling Mts., China. Ecotoxicol Environ Saf 73:907-913

Bu H, Meng W, Zhang Y (2014) Spatial and seasonal characteristics of river water chemistry in the Taizi River in Northeast China. Environ Monit Assess 186:3619-3632

Caccia VG, Millero FJ (2003) The distribution and seasonal variation of dissolved trace metals in Florida Bay and adjacent waters. Aquat Geochem 9:111-144

Chaudry MA, Zwolsman JJG (2008) Seasonal dynamics of dissolved trace metals in the Scheldt estuary: relationship with redox conditions and phytoplankton activity. Estuaries Coasts: J CERF 31:430443

Crosa G, Froebrich J, Nikolayenko V, Stefani F, Gallid P, Calamari D (2006) Spatial and seasonal variations in the water quality of the Amu Darya River (Central Asia). Water Res 40:2237-2245
Elbaz-Poulichet F, Seidel JL, Casiot C, Tusseau-Vuillemin MH (2006) Short-term variability of dissolved trace element concentrations in the Marne and Seine rivers near Paris. Sci Total Environ 367:278287

Fedoseyeva VI (1995) Effects of $\mathrm{pH}$ and temperature on the adsorption of molybdenum on certain oxides and clays. Geochem Int 32:95-100

Hatje V, Apte SC, Hales LT, Birch GF (2003) Dissolved trace metal distributions in Port Jackson estuary (Sydney Harbour), Australia. Mar Pollut Bull 46:719-730

Kowalkowski T, Zbytniewski R, Szpejna J, Buszewski B (2006) Application of chemometrics in river water classification. Water Res 40:744-752

Kumaresan M, Riyazuddin P (2008) Factor analysis and linear regression model (LRM) of metal speciation and physico-chemical characters of groundwater samples. Environ Monit Assess 138:65-79

Kuppusamy MR, Giridhar VV (2006) Factor analysis of water quality characteristics including trace metal speciation in the coastal environmental system of Chennai Ennore. Environ Int 32: 174-179

Martin JM, Guan DM, Elbaz-Poulichet F, Thomas AJ, Gordeev VV (1993) Preliminary assessment of the distribution of some trace elements ( $\mathrm{As}, \mathrm{Cd}, \mathrm{Cu}, \mathrm{Fe}, \mathrm{Ni}, \mathrm{Pb}$ and $\mathrm{Zn}$ ) in a pristine aquatic environment: the Lena River estuary (Russia). Mar Chem 43:185-199

Mendiguchía C, Moreno C, García-Vargas M (2007) Evaluation of natural and anthropogenic influences on the Guadalquivir River (Spain) by dissolved heavy metals and nutrients. Chemosphere 69:15091517

Morales MM, Marti P, Llopies A, Campos L, Sagrado S (1999) An environmental study by factor analysis of surface seawaters in the Gulf of Valencia (Western Mediterranean). Anal Chim Acta 394: 109-117

Neal C, Robson AJ, Jeffery HA, Harrow ML et al (1997) Trace element inter-relationships for the Humber Rivers: inferences for hydrological and chemical controls. Sci Total Environ 194(195):321-343

Pekey H, Karakaş D, Bakoǵlu M (2004) Source apportionment of trace metals in surface waters of a polluted stream using multivariate statistical analyses. Mar Pollut Bull 49:809-818

Ramessur RT, Parry SJ, Ramjeawon T (2001) The relationship of dissolved $\mathrm{Pb}$ to some dissolved trace metals ( $\mathrm{Al}, \mathrm{Cr}, \mathrm{Mn}$, and $\mathrm{Zn}$ ) and to dissolved nitrate and phosphate in a freshwater aquatic system in Mauritius. Environ Int 26:223-230

Ravichandran S (2003) Hydrological influences on the water quality trends in Tamiraparani Basin, South India. Environ Monit Assess 87:293-309

Shen Z, Zhang Q, Yue C et al (2006) The spatial pattern of land use/land cover in the water supplying area of the Middle-Route of the Southto-North Water Diversion (MR-SNWD) Project. Acta Geograph Sin 61:633-644 (in Chinese)

Shiller AM (1997) Dissolved trace elements in the Mississippi River: seasonal, interannual, and decadal variability. Geochim Cosmochim Acta 61:21-30

Shiller AM, Boyle EA (1985) Dissolved zinc in rivers. Nature 317:49-52

Shiller AM, Boyle EA (1987) Dissolved vanadium in rivers and estuaries. Earth Planet Sci Lett 56:214-224

Tan X, Sheldon F, Bunn SE, Zhang Q (2013) Using diatom indices for water quality assessment in a subtropical river, China. Environ Sci Pollut Res 20:4164-4175

Wang R, You C, Chu H, Huang J (2009) Seasonal variability of dissolved major and trace elements in the Gaoping (Kaoping) River Estuary, Southwestern Taiwan. J Mar Syst 76:444-456

Zhang Q, Shen Z, Xu Z, Liu G, Wang S (2009) The Han River Watershed Management Initiative for the South-to-North Water Transfer Project (Middle Route) of China. Environ Monit Assess 148: $369-377$ 
Zhou J, Liu Y, Abrahams PW (2003) Trace metal behaviour in the Conwy estuary, North Wales. Chemosphere 51:429-440

Zhou F, Guo H, Liu L (2007) Quantitative identification and source apportionment of anthropogenic heavy metals in marine sediment of Hong Kong. Environ Geol 53:295-305
Zwolsman J, Van Eck B, Van Der Weijden C (1997) Geochemistry of dissolved trace metals (cadmium, copper, zinc) in the Scheldt estuary, southwestern Netherlands: impact of seasonal variability. Geochim Cosmochim Acta 61:1635-1652 